\title{
The Analysis Source Text from the Novel with the Title "Chamber of Secret" written by JK Rolling with Using Software Monoconc Pro (MonoPro)
}

\author{
Ari Fajria Novari ${ }^{1}$ \\ ${ }^{1}$ English Education Study Program of Teacher Training and Education Faculty, Universitas Mathla'ul Anwar Banten
}

\section{ARTICLE INFO}

Keywords:

Source Text

Novel JK Rolling

Software Monoconc Pro

\begin{abstract}
The purposes of this research is to analysis the source text from the novel with the title "chamberof the secret" written by JK Wrolling with using software monoconc Pro (MonoPro). This researchused software Monoconc Pro (MonoPro) Version 2.0 invented by Michael Barlow as a tool in theanalysis contributes a great role. As corpus software that functions to show the concordance ofwords, this tool starts the analysis by searching the focusing word 'eyes'. Finding of this researchshowed that the making meaning is the most important aspect to avid readers since it is the placewhere the unity of the novel is. The research was done by using corpus-based analysis which itprovides objective result as it was gave evidences. In order to make meaning to the novel, theresearch made by searching on how the similarity of words that occur mostly in the novel andconclude the meaning by seeing on how they show based on its sentences and/ or its context asthis research has done.
\end{abstract}

This is an open access article distributed under the terms of the Creative Commons Attribution 4.0 International License, which permits unrestricted use, distribution, and reproduction in any medium, provided the original work is properly cited. @ 2019 Ari Fajria Novari.

\section{INTRODUCTION}

Language a symbolic, rule-driven system of conventional signs employed for purposes of communication, self-expression, representation, thinking, definition of the world and reality, storage and transmission of knowledge, establishing and maintaining of social relations, supporting and participating in group identities, incorporating new members into an existing group, marking boundaries with or excluding other individuals or groups, and the creative and procreative transformation of the world. Language structures and informs the way in which speakers of that language understand the world (Sapir-Whorf Hypothesis, Edward Sapir and Benjamin Whorf). People's sense of reality is embedded and embodied in the language which they speak. Rather than describing the objective, external world, language creates a subjective perception of it which is specific to that language and shared by its speakers.

${ }^{1}$ Corresponding author's address: English Education Study Program of Teacher Training and Education Faculty, Universitas Mathla'ul Anwar, Banten, Indonesia e-mail: ari.fajria@gmail.com 
A brief explanation about the importance of corpus linguistics for human language development above may raise our awareness about the thing that we called Corpus Linguistics. Corpus is a body of written text or transcribed speech which can serve as a basis for linguistic analysis and description. (Kennedy, p.1) Corpus linguistics is also come to embody methodologies for linguistic description in which quantification of the distribution of linguistic items is part of the research activity. By using corpus linguistics analysis, human may able to find out of how much further the development of the language which is used by them. Human may find the archetypes of many different languages in the world. It is very helpful for human to study a new language beside their mother tongue because the corpus analysis provides the knowledge about the main elements and the structural patterns that human should know about languages and its applications.

\section{METHOD}

The analysis in this paper uses the text taken from a novel. The source text is taken from the novel Chamber of Secret written by JK Rolling. The writer downloaded the novel from the internet and finally got the e-book version of the novel. The novel is chosen because of several factors such as: The amount of words that consist in the novel is 85.427 words. The writer downloaded the novel from the internet. After that copy them into notepad and insert to corpus software Monoconc Pro (MonoPro) Version 2.0 invented by Michael Barlow as a tool in the analysis contributes a great role. As corpus software that functions to show the concordance of words, this tool starts the analysis by searching the focusing word 'eyes'. Indeed, the format of the novel, Portable Document Format (PDF), which is taken from the e-book version have been transferred first to the format of text document (txt) and had been loaded to the software afterwards. Then, it records, the number of matches or occurrences of the words showed in the concordance tab.

\section{RESULT AND DISCUSSION}

\section{Finding}

After processing the raw text in Monoconc Pro software, it is found that there are 146 occurrences of "eyes" in the text. This corpus based analysis deals with numbers of words as the focus. Thus, there are several findings in the analysis as following. From 85.427 words existed in the novel, there are 146 matches as concordance of 'eyes' in the novel and it reaches $0,1677 \%$ in percentage.

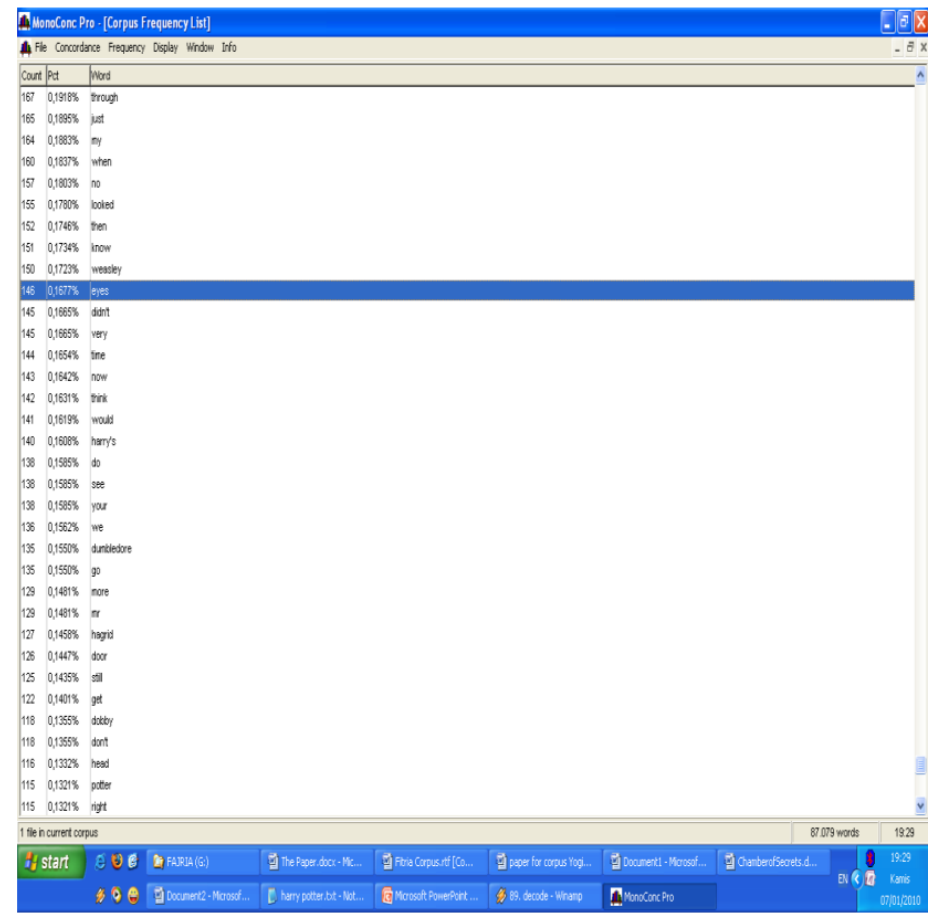

Picture 3.1. Corpus frequency list for the novel 
1 ... tums," said Aunt Petunia, turning misty [[eyes]] on her massive son. "We must build you ...

$2 \ldots$ out of the corners of his small, sharp [[eyes]]. Ever since Harry had come home for th ...

3 ... small and skinny, with brilliant green [[eyes]] and jet-black hair that was always unti ...

4 ... membering his livid face, his wide, mad [[eyes]]... Harry suddenly sat bolt upright on ...

5 ... ge was staring back. Two enormous green [[eyes]] had appeared among the leaves. Harry j ...

6 ... Dudley, waddling toward him. The huge [[eyes]] blinked and vanished. "What?" said Har ...

7 ... ed. "What?" said Harry, not taking his [[eyes]] off the spot where they had been. "I k ...

8 ... large, bat-like ears and bulging green [[eyes]] the size of tennis balls. Harry knew in ...

9 ... control himself, and sat with his great [[eyes]] fixed on Harry in an expression of wate ...

10 ... st," said Dobby reverently, his orblike [[eyes]] aglow. "Harry Potter speaks not of his ...

$11 \ldots$ l. 1, too. Dobby leaned toward Harry, his [[eyes]] wide as headlights. 'Dobby heard tell, ...

12 ... yet again. "Harry nodded and Dobby's [[eyes]] suddenly shone with tears. "Ah, sir," ...

13 ... -Must-Not-Be-Named, sir. ' But Dobby's [[eyes]] were wide and he seemed to be trying to ...

14 ... er, has he?" Dobby shook his head, his [[eyes]] wider than ever. "Well then, I can't $t$...

15 ... ced on him, a demonic glint in his tiny [[eyes]]. "Read it!" he hissed evilly, brandish ...

16 ... ncle Vernon, a mad gleam dancing in his [[eyes]]. "For got to mention it... Slipped you're ...

17 ... I'm trying to sleep..." He opened his [[eyes]]. Moonlight was shining through the bars ...

$18 \ldots$ on had gone a nasty greenish color, his [[eyes]] fixed on the house. The other three whe ...

19 ... rd with wavy blond hair and bright blue [[eyes]]. As always in the wizarding world, the ...

$20 \ldots \mathrm{m}$. The garden was large, and in Harry's [[eyes]], exactly what a garden should be. The D ...

$21 \ldots$ chen chair with his glasses off and his [[eyes]] closed. He was a thin man, going bald, ...

22 ... long poker like a sword. Mr. Weasley's [[eyes]] jerked open. He stared guiltily at his ...

23 ... , Arthur, cars," said Mrs. Weasley, her [[eyes]] flashing. "Imagine a wizard buying a ru ...

24 ... ered as sparks flew from Mrs. Weasley's [[eyes]], "that - that was very wrong, boys - very w

...

25 ... caught sight of a pair of bright brown [[eyes]] staring at him before it closed with a ...

26 ... ows tucked in," Ron advised. "And your [[eyes]] shut," said Mrs. Weasley. "The soot-" ...

27 ... ars was deafening -he tried to keep his [[eyes]] open but the whirl of green flames made ...

28 ... were churning inside him - he closed his [[eyes]] again wishing it would stop, and then $-\mathrm{h} . .$.

$29 \ldots \mathrm{t}$, holding his broken glasses up to his [[eyes]]. He was quite alone, but where he was, ...

$30 \ldots$, pointed face and identical cold, gray [[eyes]]. Mr. Malfoy crossed the shop, looking 1

$\cdots$

31 ... came striding toward them, beetle-black [[eyes]] flashing over his great bristling beard ...

32 ... et-me-not blue that exactly matched his [[eyes]]; his pointed wizard's hat was set at a ...

33 ... . "Clearly," said Mr. Malfoy, his pale [[eyes]] straying to Mr. and Mrs. Granger, who w ...

34 ... guration book. He thrust it at her, his [[eyes]] glittering with malice. "Here, girl-ta ...

$35 \ldots \mathrm{d}$ to place the hat on his head. Harry's [[eyes]] wandered past him to where Professor $\mathrm{Du} \ldots$

36 ... he was unable to look Dumbledore in the [[eyes]], and spoke instead to his knees. He tol ...

37 ... a lightning scar on your forehead" (his [[eyes]] raked Harry's hairline) "and a boy in $\mathrm{m}$...

38 ... Professor Flitwick squarely between the [[eyes]], creating a large, throbbing green boil ...

39 ... urly sixth year and, at the moment, his [[eyes]] were gleaming with a crazed enthusiasm ...

40 ... Malfoy was smirking so broadly his cold [[eyes]] were reduced to slits. "Oh, look," sai ...

41 ... "Don' think he did," said Hagrid, his [[eyes]] twinkling. "An' then I told him Id neve ...

42 ... gazing into a pair of lamp-like yellow [[eyes]]. It was Mrs. Norris, the skeletal gray ...

43 ... th!" he shouted, his jowls aquiver, his [[eyes]] popping alarmingly as he pointed at the ...

44 ... e Peeves out this time, my sweet." His [[eyes]] fell on Harry and then darted to the Kw ...

45 ... med; Filch had never looked madder. His [[eyes]] were popping, a tic was going in one of ...

46 ... ng about poor Myrtle," said Peeves, his [[eyes]] dancing. "Rude you was about poor Myrtl ...

47 ... lling rapidly in her small, see-through [[eyes]]. "No-honestly-didn't I just say how ni ... 
48 ... im, and they inched toward the message, [[eyes]] fixed on a dark shadow beneath it. All ... 49 ... bracket. She was stiff as a board, her [[eyes]] wide and staring. For a few seconds, $t$... $50 \ldots$ hed to the front of the crowd, his cold [[eyes]] alive, his usually bloodless face flush ...

Table 1. The contextual meaning of the word "eyes" in the novel Chamber of Secret written by JK Rolling. Lets the following list.

\begin{tabular}{|c|c|c|c|}
\hline Data & Form & Frequency & $\begin{array}{c}\text { Make } \\
\text { Meaning }\end{array}$ \\
\hline $\begin{array}{l}\text {... He cleared his } \\
\text { throat, and the } \\
\text { emerald [[eyes]] } \\
\text { seemed to flicker. } \\
\text { “Open, “said Harry, ... }\end{array}$ & noun & 33 & $\begin{array}{l}\text { Symbols of } \\
\text { feeling }\end{array}$ \\
\hline $\begin{array}{l}\text {... ed toward her, she } \\
\text { sat up. Her be-mused } \\
\text { [[eyes]] traveled from } \\
\text { the huge form of the } \\
\text { dead ... }\end{array}$ & noun & 42 & $\begin{array}{l}\text { Live and } \\
\text { happen }\end{array}$ \\
\hline $\begin{array}{c}\text {... thering heavily } \\
\text { across the dusty floor. } \\
\text { [[Eyes]] still tightly } \\
\text { shut, Harry began to } \\
\text { run ... }\end{array}$ & Noun & 41 & $\begin{array}{l}\text { Doing to } \\
\text { something }\end{array}$ \\
\hline $\begin{array}{l}\text {... ts eyes, both its } \\
\text { great, bulbous yellow } \\
\text { [[eyes]], had been } \\
\text { punctured by the } \\
\text { phoenix; blo ... }\end{array}$ & Noun & 17 & $\begin{array}{l}\text { The quality of } \\
\text { something }\end{array}$ \\
\hline $\begin{array}{c}\text {..., Arthur, cars," said } \\
\text { Mrs. Weasley, her } \\
\text { [[eyes]] flashing. } \\
\text { "Imagine a wizard } \\
\text { buying a ru ... }\end{array}$ & noun & 13 & $\begin{array}{c}\text { The power of } \\
\text { magic }\end{array}$ \\
\hline
\end{tabular}

\section{Discussion}

1. Symbols of the something

He cleared his throat, and the emerald [[eyes]] seemed to flicker.

$\rightarrow$ Harry has doing something to this situation, he feel a scared.

2. Live and happen

Her be-mused [[eyes]] traveled from the huge form of the dead basilisk, over Harry, in his blood-soaked robes, then to the diary in his hand.

$\rightarrow$ She made a changed the situation.

3. Doing to something [[Eyes]] still tightly shut, Harry began to run blindly sideways, his hands outstretched, feeling his way - Voldemort was laughing...

$\rightarrow$ when Harry was groan because in the near Voldemort, and Voldemort was laughing.

4. The quality of something

The snake's tail thrashed, narrowly missing Harry, and before Harry could shut his eyes, it turned-Harry looked straight into its face and saw that its eyes, both its great, bulbous yellow [[eyes]], had been punctured by the phoenix; blood was streaming to the floor, and the snake was spitting in agony. 
$\rightarrow$ his eyes gave the spirit.

5. The power of magic

"Yes, Arthur, cars," said Mrs. Weasley, her [[eyes]] are flashing.

$\rightarrow$ Mrs. Weasley was sharp looking Mrs. Weasley because his car.

\section{CONCLUSION}

The development of language is merely captured in the field of literature. Literary works such as novel is one of many sources which phenomena of language can be found as it may serve many interpretations to the readers. Such phenomena are what familiarly called figurative language. The contribution of figurative language to the enrichment of the language should be regarded as one of the most various.

Reading novel at the end should result meanings. Multi-interpretation of figurative language should, at the end, be fixed so that it cannot just mean anything. Thus, the making meaning is the most important aspect to avid readers since it is the place where the unity of the novel is. The investigation was done by using corpus-based analysis which it provides objective result as it was gave evidences. In order to make meaning to the novel, the investigation made by searching on how the similarity of words that occur mostly in the novel and conclude the meaning by seeing on how they show based on its sentences and/ or its context as this research has done.

\section{REFERENCE}

Kennedy, G. D. (1998). An introduction to corpus linguistics. London: Longman.

Thomas, J. (1995). Meaning in interaction: An introduction to pragmatics. London: Longman.

Microsoft Encarta Premium Dictionary (1998). Language File: Material for an introduction to language and linguistics. Ohio: Ohio State University Press 